Journal of Clinical Investigation

Vol. 42, No. 11, 1963

\title{
CORRELATION OF PLASMA ACTH CONCENTRATION WITH ADRENOCORTICAL RESPONSE IN NORMAL HUMAN SUBJECTS, SURGICAL PATIENTS, AND PA- TIENTS WITH CUSHING'S DISEASE *
}

\author{
By ROBERT L. NEY, NAOKATA SHIMIZU, † WENDELL E. NICHOLSON, \\ DONALD P. ISLAND, AND GRANT W. LIDDLE \\ (From the Department of Medicine, Vanderbilt University School of Medicine, \\ Nashville, Tenn.)
}

(Submitted for publication March 25, 1963; accepted July 11, 1963)

The role of $\mathrm{ACTH}$ in various clinical disorders has been difficult to ascertain because the available assay methods have lacked the sensitivity necessary for valid quantitation of the hormone in the plasma of normal subjects (1-4). Even the method of Lipscomb and Nelson (5), the most sensitive practical bioassay procedure now available, usually requires the injection of at least $0.05 \mathrm{mU}$ of ACTH per rat, if responses are to be elicited that will be statistically significant without the use of a prohibitive number of animals. It is usually impractical to inject more than $5 \mathrm{ml}$ of crude human plasma into a single rat. Therefore, in order to be accurately measurable by this procedure, the concentration of $\mathrm{ACTH}$ in the plasma must be at least $0.05 \mathrm{mU}$ per $5 \mathrm{ml}$, or 1 $\mathrm{mU}$ per $100 \mathrm{ml}$.

Numerous studies indicate that normal plasma levels of ACTH are well below this concentration. By the adrenal ascorbic acid depletion assay method, Sydnor, Sayers, Brown, and Tyler (1) were unable to detect ACTH in plasma of normal subjects, even after attempting to extract the hormone with oxycellulose in preparation for the bioassay. These workers concluded that blood ACTH concentrations of normal human subjects were less than $0.5 \mathrm{mU}$ per $100 \mathrm{ml}$. Using a similar procedure, Fujita (3) estimated the normal level of ACTH to be about $1 \mathrm{mU}$ per L, i.e., 0.1 $\mathrm{mU}$ per $100 \mathrm{ml}$. Cooper and Nelson (6) were able to detect $\mathrm{ACTH}$ in the plasma of only 3 of 10 patients before surgery, by a method that they

* Presented in part at the 44th annual meeting of The Endocrine Society, June, 1962, Chicago, Ill. These studies were supported in part by U. S. Public Health Service grants-in-aid 5T1-5092, AM-05318, and OG-2.

† Permanent address: 1st Medical Department, University of Tokyo School of Medicine, Tokyo, Japan. thought would enable them to detect $0.6 \mathrm{mU}$ per $100 \mathrm{ml}$ of plasma.

In contrast to these low values, Vance, Reddy, Nelson, and Thorn (7) have recently reported the value of $0.8 \mathrm{mU}$ per $100 \mathrm{ml}$ in the plasma of most normal individuals tested. In some of the assays, however, only single-dose levels of plasma were used, and when multiple-dose levels of normal plasma were used, significant regression of the dose-response curves was not demonstrated. The limitations of single-dose level biological assays are well recognized (8). Paris and his associates (9), Sayers (10), and Munson (11) have emphasized the desirability of performing ACTH assays using multiple-dose levels of both the unknown and a standard.

Our efforts to measure normal levels of ACTH in plasma have been greatly facilitated by concentrating the hormone into a small volume before injection into the assay animals $(12,13)$. It has thus been possible to inject into a single assay animal the ACTH from as much as $80 \mathrm{ml}$ of plasma. Multiple-dose levels have been employed, and dose-response curves have been obtained that extend into the range corresponding to the steep portion of the dose-response curve obtained with the U.S.P. standard.

The statistical analyses of the ACTH assay data in the present study were designed to answer four questions. The first three are concerned with individual plasma specimens, whereas the fourth is concerned with the assessment of possible differences among groups of specimens. First, what is the potency of each unknown specimen compared with the U.S.P. standard? Second, what are the confidence limits on this estimate of potency? Third, is the response to the unknown specimen significantly different from the response 
to saline controls? Fourth, are the values obtained for one group of specimens significantly different from those obtained for another group (e.g., plasma from normal subjects versus plasma from patients with Cushing's disease)?

With these considerations in mind, we have attempted to determine the concentrations of ACTH in normal human plasma and to explore the quantitative relationship between ACTH concentrations and the degree of adrenocortical activity as judged from measurements of plasma and urinary 17-hydroxycorticosteroids (17-OHCS). Under ordinary nonstressful circumstances, both the plasma ACTH concentration and the degree of adrenocortical activity were found to be confined to rather narrow ranges. In order to extend these ranges, constant iv infusions of exogenous ACTH were administered for periods of 24 hours. Nomograms relating plasma ACTH concentration to plasma and urinary corticosteroids were constructed for normal subjects. In similar fashion, the relationships between steroid levels and endogenous ACTH levels were studied in patients with Cushing's disease ${ }^{1}$ and in patients undergoing surgery.

\section{METHODS}

Healthy young men served as subjects for these studies. On 28 occasions, 9 subjects received constant 24-hour infusions of $1,500 \mathrm{ml}$ of $0.9 \%$ saline to which ACTH ${ }^{2}$ had been added. The rate of infusion of ACTH for the different studies ranged between 0.02 and $3.0 \mathrm{U}$ per hour. The infusions were begun at 8 a.m., and blood specimens for ACTH and 17-OHCS determinations were obtained at 6 p.m. and 6 a.m. during the infusions. At least 6 days elapsed between any two infusions.

For our study of the diurnal fluctuation in plasmaACTH levels of normal subjects, 5 healthy young men received constant 24 -hour infusions of $1,500 \mathrm{ml}$ of $0.9 \%$ saline, without added ACTH. Blood specimens (usually about $500 \mathrm{ml}$ ) were drawn at 6 p.m. and 6 a.m. during the infusions. To extend these observations, blood specimens were also drawn at 6 p.m. and 6 a.m. on 8 occasions from 6 normal subjects who were ambulatory and carrying out their usual activities.

Blood specimens were obtained during the course of

1 "Cushing's disease" in this paper refers to hypercortisolism that may be presumed to be secondary to secretion of ACTH by the pituitary as judged from the qualitatively normal responses of steroid levels to standard tests with dexamethasone (14) and Metopirone (15).

2 Porcine ACTH, Parke, Davis and Company, Detroit, Mich. major surgical procedures from 11 patients who had no apparent endocrine disease and who were not receiving corticosteroids or ACTH. In addition, blood and urine specimens were obtained from 9 patients with Cushing's disease at times when they were receiving no medications and were free from any apparent stress. In all our studies, plasma (16) and urinary (17) 17-OHCS were determined by modifications of Silber and Porter's method.

In preparation for the assay of ACTH in plasma, the hormone was extracted into a small volume with a carboxylic resin (Amberlite IRC-50, XE-64), by our previously f.ublished method (12). Earlier studies (13) have shown excellent recoveries of ACTH by this method, in concentrations ranging from 1.7 to $46 \mathrm{mU}$ per $100 \mathrm{ml}$ plasma. The recovery experiments have recently been extended by use of plasma containing no endogenous ACTH, with known quantities of U.S.P. ACTH added to give final concentrations ranging from 0.10 to $0.89 \mathrm{mU}$ per $100 \mathrm{ml}$. The ACTH was then extracted and assayed by the procedures outlined in this section. In 11 such experiments, the mean recovery was $102 \%$ with a SD of $41 \%$.

The bioassay procedure was a modification of that described by Lipscomb and Nelson (5). Male SpragueDawley rats, each weighing approximately $200 \mathrm{~g}$, were hypophysectomized by a transaural approach. Two hours after hypophysectomy, the material to be assayed was injected into the femoral vein, followed by $250 \mathrm{U}$ of heparin. From minutes 7 to 10 after the injection, blood was drawn continuously from the left adrenal vein by the technique of Munson and Toepel (18). The corticosterone content of the adrenal venous blood, determined by the method of Silber, Busch, and Oslapas (19), served as the index of dosage of ACTH.

On every assay day, 3 rats received saline, and 3 rats at each of 3 dose levels were treated with U.S.P. ACTH. Plasma extracts were tested at 2 or more dose levels, with fourfold dosage intervals, and with 3 rats at each level. For each assay, the mean estimate of potency of the unknown relative to U.S.P. ACTH and the 95\% confidence limits on that estimate were calculated by the method of Sayers, Sayers, and Woodbury (20). By standard methods of calculating potency (with a linear logarithmic dose-response curve), it is impossible to derive a value of "zero" potency even when one knows that there is no ACTH in the solution injected. We have, therefore, compared the responses elicited by the high dose of each unknown extract with those elicited by saline controls. The $t$ test (one-tailed) has been applied to determine whether the quantities of ACTH were significant $(p<0.05)$. In actual practice, the responses to an unknown might be NS for a number of reasons. There might be a negligible quantity of $\mathrm{ACTH}$ present. On the other hand, ACTH might be present, but the number of animals tested might be too small to establish the point unequivocally.

A particular specimen need not differ significantly from the saline control in order to be combined with 
several others and establish that one group of specimens differs significantly from another group. Thus, in comparison of one group of specimens with another (e.g., normal a.m. versus normal p.m.), the mean of the potencies for each group was calculated, and the significance of the difference between means was evaluated by the $t$ test (two-tailed, $\mathrm{p}<0.05$ ).

\section{RESULTS}

The quantities of normal plasma required for assaying $A C T H$. ACTH could not be measured with certainty in crude plasma from normal subjects even when quantities as great as $5 \mathrm{ml}$ were injected into each rat. Extraction of ACTH with IRC-50 resin, however, reduced the volume so much that the equivalent of as much as $80 \mathrm{ml}$ of plasma could be injected into a single rat. As illustrated in Figure 1, concentrated extracts representing $10 \mathrm{ml}$ of plasma per rat failed to establish a dose-response curve with regression significantly different from zero even though 10 animals were used. With extracts containing the equivalent of $20 \mathrm{ml}$ of plasma, however, responses were observed that were significantly greater than those elicited by saline injections $(p<0.05)$. At this dose level, an average of 4 rats was necessary to establish the presence of significant amounts of

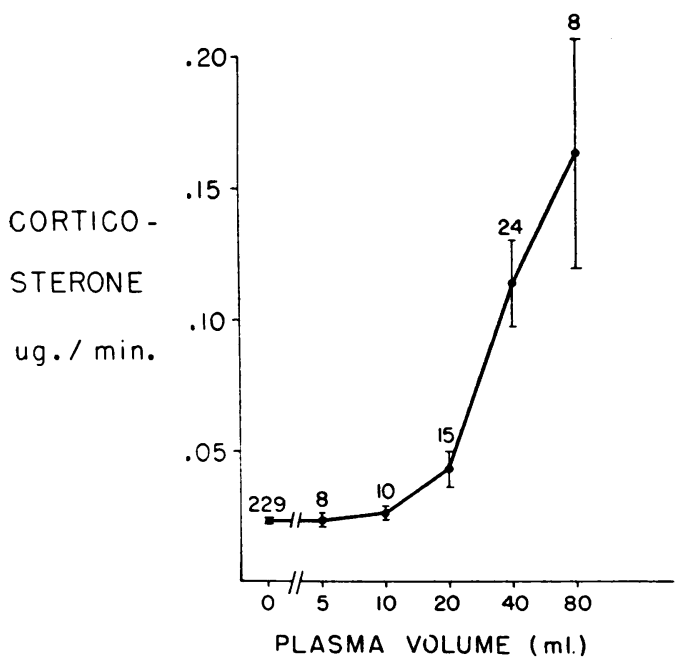

Fig. 1. Adrenal venous corticosterone of hypoPHYSECTOMIZED RATS IN RESPONSE TO GRADED DOSES OF PLASMa obtained From 11 NORMal SUbJects at 6 A.M. For volumes greater than $5 \mathrm{ml}$, the plasma specimens were extracted; the quantities of plasma equivalent to the extracts are indicated on the abscissa. Vertical bars represent $\mathrm{SE}$ at each dose level. Numbers above the hars indicate the numbers of rats tested.
TABLE I

Diurnal variation in plasma ACTH and 17-OHCS concentrations in normal subjects*

\begin{tabular}{|c|c|c|c|}
\hline Subject & Time & Plasma ACTH & $\underset{17-O H C S}{\text { Plasma }}$ \\
\hline F.D. & $\begin{array}{l}6 \text { a.m. } \\
6 \text { p.m. }\end{array}$ & $\begin{array}{c}m U / 100 m l \\
0.19(0.13-0.28) \\
0.06(0.01-0.28) \dagger\end{array}$ & $\begin{array}{c}\mu g / 100 m l \\
23 \\
11\end{array}$ \\
\hline T.S. & $\begin{array}{l}6 \text { a.m. } \\
6 \text { p.m. }\end{array}$ & $\begin{array}{l}0.17(0.08-0.37) \dagger \\
0.10(0.05-0.20) \dagger\end{array}$ & $\begin{array}{l}26 \\
11\end{array}$ \\
\hline J.G. & $\begin{array}{l}6 \text { a.m. } \\
6 \text { p.m. }\end{array}$ & $\begin{array}{l}0.11(0.05-0.24) \dagger \\
0.05(0.01-0.59) \dagger\end{array}$ & $\frac{20}{7}$ \\
\hline F.D. & $\begin{array}{l}6 \text { a.m. } \\
6 \text { p.m. }\end{array}$ & $\begin{array}{l}0.18(0.08-0.39) \dagger \\
0.04(0.003-0.45) \dagger\end{array}$ & $\begin{array}{l}21 \\
10\end{array}$ \\
\hline T.E. & $\begin{array}{l}6 \text { a.m. } \\
6 \text { p.m. }\end{array}$ & $\begin{array}{l}0.15(0.07-0.33) \dagger \\
0.10(0.02-0.54) \dagger\end{array}$ & $\begin{array}{l}27 \\
12\end{array}$ \\
\hline F.H. & $\begin{array}{l}6 \text { a.m. } \\
6 \text { p.m. }\end{array}$ & $\begin{array}{l}0.59(0.41-0.85) \\
0.06(0.02-0.17) \dagger\end{array}$ & $\begin{array}{r}21 \\
3\end{array}$ \\
\hline K.B. & $\begin{array}{l}6 \text { a.m. } \\
6 \text { p.m. }\end{array}$ & $\begin{array}{l}0.10(0.06-0.15) \\
0.10(0.06-0.15) \dagger\end{array}$ & $\begin{array}{r}16 \\
8\end{array}$ \\
\hline H.M. & 6 a.m. & $0.30(0.17-0.55)$ & 15 \\
\hline J.G. & 6 a.m. & $0.56(0.35-0.89)$ & 16 \\
\hline M.J. & 6 a.m. & $0.40(0.26-0.61)$ & 22 \\
\hline S.M. & $\begin{array}{l}6 \text { a.m. } \\
6 \text { p.m. }\end{array}$ & $\begin{array}{l}0.19(0.08-0.43) \dagger \\
0.23(0.10-0.51) \dagger\end{array}$ & $\begin{array}{l}20 \\
11\end{array}$ \\
\hline T.F. & $\begin{array}{l}6 \text { a.m. } \\
6 \text { p.m. }\end{array}$ & $\begin{array}{l}0.10(0.03-0.31) \dagger \\
0.10(0.03-0.32) \dagger\end{array}$ & $\begin{array}{l}21 \\
16\end{array}$ \\
\hline B.C. & $\begin{array}{l}6 \text { a.m. } \\
6 \text { p.m. }\end{array}$ & $\begin{array}{l}0.19(0.07-0.48) \dagger \\
0.25(0.08-0.73)\end{array}$ & $\begin{array}{l}14 \\
13\end{array}$ \\
\hline
\end{tabular}

* The mean estimate of potency is indicated for each ACTH determination, and $95 \%$ confidence limits are shown in parentheses.

$t$ Assays in which responses elicited by the high dose of the unknown were not significantly different from saline controls when compared by the student $t$ test (one-tailed, $\mathrm{p}>0.05$ ).

ACTH. At the higher dose levels (up to the equivalent of $80 \mathrm{ml}$ of plasma), 3 rats, on the average, were needed to establish that the responses elicited by the extract were significantly different from saline responses. Significant regression of the dose-response curve was observed when the injection into each rat represented the ACTH extracted from 20 to $80 \mathrm{ml}$ of normal plasma. In general, then, it was necessary to obtain about 250 $\mathrm{ml}$ of plasma from the normal subjects for ACTH assays. To be certain that the phlebotomy did not by itself induce a discharge of $\mathrm{ACTH}$, a 10 $\mathrm{ml}$ blood specimen for 17-OHCS determination was obtained 30 minutes after the initial venipuncture. Since the phlebotomy was never followed by an increase in plasma 17-OHCS, we assumed that it was not in itself causing an appreciable increase in the ACTH level.

Diurnal variation of plasma ACTH and correlation with plasma corticosteroids in normal subjects. The concentrations of ACTH and 17OHCS in plasma obtained from normal subjects at 6 p.m. have been compared with those obtained at 6 a.m. (Table I and Figure 2). For 


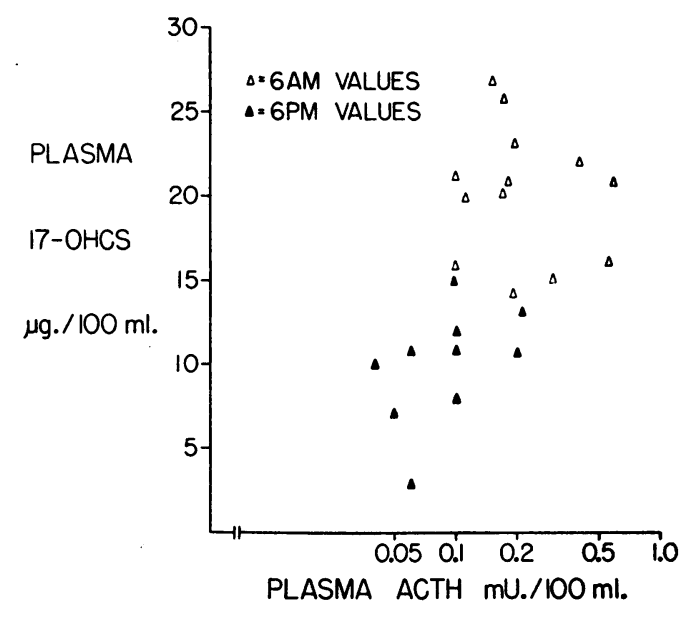

Fig. 2. Diurnal variation in plasma ACTH and 17-OHCS IN NORMAL MAN. Each value is a coordinate for simultaneous plasma $\mathrm{ACTH}$ and 17-OHCS concentrations.

the 6 p.m. specimens, the estimates of $\mathrm{ACTH}$ in individual specimens ranged from 0.04 to 0.25 $\mathrm{mU}$ per $100 \mathrm{ml}$, with a mean for the group of $0.11 \mathrm{mU}$ per $100 \mathrm{ml}$. The concentrations of 17 OHCS in specimens of plasma obtained at 6 p.m. ranged from 3 to $16 \mu \mathrm{g}$ per $100 \mathrm{ml}$.

At 6 a.m., plasma 17-OHCS were found to be in the range of 14 to $27 \mu \mathrm{g}$ per $100 \mathrm{ml}$. The

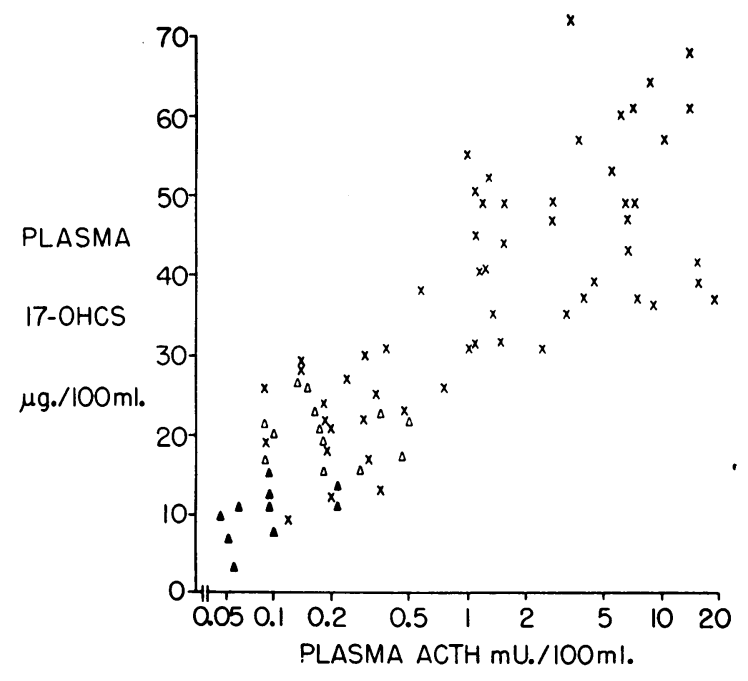

Fig. 3. Each point Represents a coordinate value FOR. SIMUlTANEOUS PLASMA ACTH AND 17-OHCS CONCEntrations. Solid triangles are the 6 p.m. and open triangles are the 6 a.m. values of untreated normal subjects shown in Figure 2. The remaining values (X) are those of normal subjects receiving 24-hour ACTH infusions. estimates of $\mathrm{ACTH}$ in individual specimens of plasma ranged from 0.10 to $0.59 \mathrm{mU}$ per $100 \mathrm{ml}$, with a group mean of $0.25 \mathrm{mU}$ per $100 \mathrm{ml}$. In 6 of the 13 individual assays, the responses were of such magnitude and consistency that it was possible to satisfy statistical criteria of significance. Taken as a group, the 6 a.m. plasma specimens contained significantly greater concentrations of ACTH than did the 6 p.m. group $(\mathrm{p}<0.025)$.

Normal subjects receiving $A C T H$ infusions. With constant infusions of exogenous ACTH.

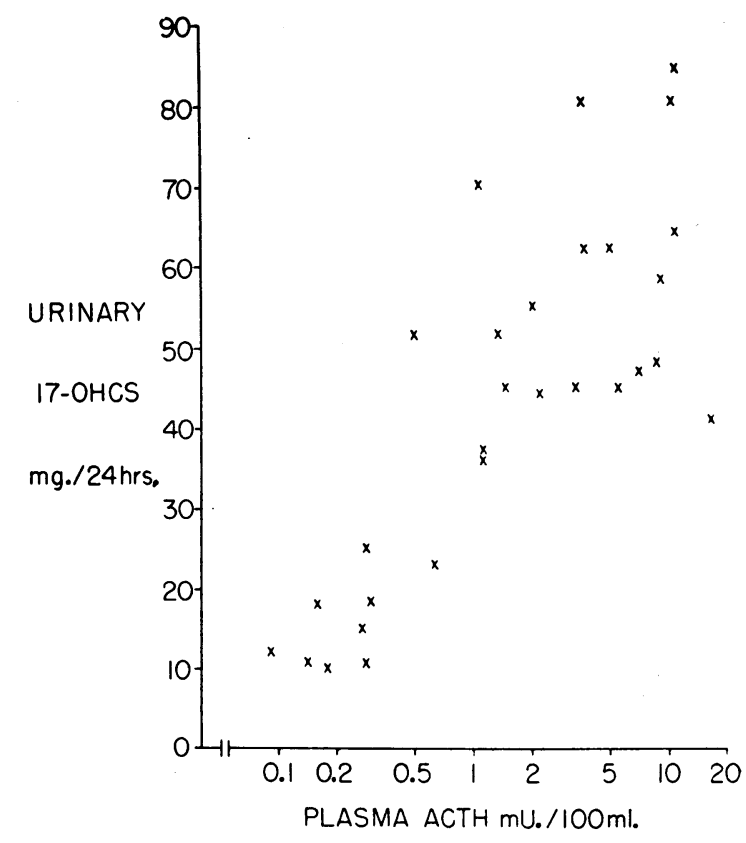

Fig. 4. Plasma ACTH concentrations and 24HOUR URINARY 17-OHCS LEVELS IN NORMAL SUBJECTS RECEIVING CONSTANT 24-hour ACTH infusions. Each ACTH value represents the mean of the 2 determinations made during the infusion.

we were able to adjust the concentration of this hormone in the plasma to any desired level. Plasma 17-OHCS concentrations could then be correlated with a wide range of ACTH concentrations. The data from this study are presented in. Table II and Figure 3. The plasma 17-OHCS concentrations appeared to be rectilinear functions of the logarithm of plasma ACTH concentration as long as the latter did not exceed $3 \mathrm{mU}$ per $100 \mathrm{ml}$. The $\mathrm{r}$ relating plasma $17-\mathrm{OHCS}$ concentrations to plasma ACTH over this range was 
TABLE II

Plasma ACTH concentrations and plasma and urinary 17-OHCS in 9 normal subjects receiving 24-hour ACTH infusions*

\begin{tabular}{|c|c|c|c|c|}
\hline Subject & $\begin{array}{l}\text { Time } \\
\text { during } \\
\text { ACTH } \\
\text { infusion }\end{array}$ & Plasma ACTH & $\begin{array}{l}\text { Plasma } \\
\text { 17-OHCS }\end{array}$ & $\begin{array}{l}\text { Urinary } \\
\text { 17-OHCS }\end{array}$ \\
\hline \multirow[t]{2}{*}{ T.E. } & $\begin{array}{c}\text { hours } \\
10 \\
22\end{array}$ & $\begin{array}{c}m U / 100 m l \\
5.56(3.93-7.88) \\
4.23(3.26-5.49)\end{array}$ & $\begin{array}{c}\mu \mathrm{g} / 100 \mathrm{ml} \\
53 \\
50\end{array}$ & $\begin{array}{c}m g / 2+\text { hours } \\
62\end{array}$ \\
\hline & $\begin{array}{l}10 \\
22\end{array}$ & $\begin{array}{c}10.18(5.30-19.4) \\
7.07(5.30-9.4)\end{array}$ & $\begin{array}{l}57 \\
61\end{array}$ & 58 \\
\hline \multirow[t]{2}{*}{ F.H. } & $\begin{array}{l}10 \\
22\end{array}$ & $\begin{array}{r}14.09(8.50-23.3) \\
6.33(4.67-8.59)\end{array}$ & $\begin{array}{l}68 \\
60\end{array}$ & 80 \\
\hline & $\begin{array}{l}10 \\
22\end{array}$ & $\begin{array}{r}14.26(8.60-23.70) \\
8.67(5.90-12.70)\end{array}$ & $\begin{array}{l}61 \\
64\end{array}$ & 84 \\
\hline \multirow[t]{6}{*}{ D.G. } & $\begin{array}{l}10 \\
22\end{array}$ & $\begin{array}{l}0.09(0.03-0.28) \dagger \\
0.09(0.03-0.27) \dagger\end{array}$ & $\begin{array}{l}19 \\
26\end{array}$ & 12 \\
\hline & $\begin{array}{l}10 \\
22\end{array}$ & $\begin{array}{l}0.19(0.08-0.42) \dagger \\
0.17(0.07-0.41) \dagger\end{array}$ & $\begin{array}{l}18 \\
21\end{array}$ & 10 \\
\hline & $\begin{array}{l}10 \\
22\end{array}$ & $\begin{array}{l}1.49(0.58-3.87) \dagger \\
1.38(0.51-3.72) \dagger\end{array}$ & $\begin{array}{l}32 \\
35\end{array}$ & 45 \\
\hline & $\begin{array}{l}10 \\
22\end{array}$ & $\begin{array}{l}2.76(1.73-4.42) \\
1.52(0.58-3.95)\end{array}$ & $\begin{array}{l}47 \\
44\end{array}$ & 44 \\
\hline & $\begin{array}{l}10 \\
22\end{array}$ & $\begin{array}{l}4.00(2.89-5.54) \\
6.66(5.05-8.80)\end{array}$ & $\begin{array}{l}37 \\
43\end{array}$ & 45 \\
\hline & $\begin{array}{l}10 \\
22\end{array}$ & $\begin{array}{l}19.29(8.90-42.0) \\
15.57(7.20-33.80)\end{array}$ & $\begin{array}{l}37 \\
39\end{array}$ & 41 \\
\hline \multirow[t]{3}{*}{ T.S. } & $\begin{array}{l}10 \\
22\end{array}$ & $\begin{array}{l}1.08(0.34-3.42) \\
1.54(0.61-3.86)\end{array}$ & $\begin{array}{l}45 \\
49\end{array}$ & 52 \\
\hline & $\begin{array}{l}10 \\
22\end{array}$ & $\begin{array}{l}6.64(4.67-9.44) \\
7.27(5.39-9.80)\end{array}$ & $\begin{array}{l}47 \\
49\end{array}$ & 47 \\
\hline & $\begin{array}{l}10 \\
22\end{array}$ & $\begin{array}{l}7.45(3.67-15.12) \\
9.29(5.40-16.00)\end{array}$ & $\begin{array}{l}37 \\
36\end{array}$ & 48 \\
\hline \multirow[t]{2}{*}{ B.C. } & $\begin{array}{l}10 \\
22\end{array}$ & $\begin{array}{l}1.03(0.66-1.60) \\
1.21(0.60-2.42)\end{array}$ & $\begin{array}{l}31 \\
41\end{array}$ & 37 \\
\hline & $\begin{array}{l}10 \\
22\end{array}$ & $\begin{array}{l}1.08(0.26-4.58) \\
1.00(0.23-4.44)\end{array}$ & $\begin{array}{l}51 \\
55\end{array}$ & 70 \\
\hline \multirow[t]{3}{*}{ S.G. } & $\begin{array}{l}10 \\
22\end{array}$ & $\begin{array}{l}0.20(0.11-0.38) \dagger \\
0.36(0.20-0.66) \dagger\end{array}$ & $\begin{array}{l}12 \\
13\end{array}$ & 11 \\
\hline & $\begin{array}{l}10 \\
22\end{array}$ & $\begin{array}{l}0.12(0.04-0.32) \dagger \\
0.19(0.10-0.37)\end{array}$ & $\begin{array}{r}9 \\
22\end{array}$ & 18 \\
\hline & $\begin{array}{l}10 \\
22\end{array}$ & $\begin{array}{l}1.03(0.60-1.78) \\
1.20(0.75-1.92)\end{array}$ & $\begin{array}{l}31 \\
41\end{array}$ & 37 \\
\hline \multirow[t]{2}{*}{ R.H. } & $\begin{array}{l}10 \\
22\end{array}$ & $\begin{array}{l}0.24(0.13-0.45) \dagger \\
0.31(0.19-0.49)\end{array}$ & $\begin{array}{l}27 \\
17\end{array}$ & 25 \\
\hline & $\begin{array}{l}10 \\
22\end{array}$ & $\begin{array}{l}0.38(0.16-0.92) \\
0.59(0.35-1.00)\end{array}$ & $\begin{array}{l}31 \\
38\end{array}$ & 52 \\
\hline
\end{tabular}

* The paired values for plasma ACTH and 17-OHCS represent observations at different hours during the same infusion. The mean estimate of potency has been calculated for each ACTH assay, and $95 \%$ confidence limits are in parentheses.

$\dagger$ Assays in which responses elicited by the high dose of the unknown were not significantly different from saline controls when compared by $t$ test (one-tailed, $\mathrm{p}>0.05$ ). 
TABLE II-(Continued)

\begin{tabular}{|c|c|c|c|c|}
\hline Subject & $\begin{array}{c}\text { Time } \\
\text { during } \\
\text { ACTH } \\
\text { infusion }\end{array}$ & Plasma ACTH & $\begin{array}{l}\text { Plasma } \\
17-\mathrm{OHCS}\end{array}$ & $\begin{array}{c}\text { Urinary } \\
\text { 17-OHCS }\end{array}$ \\
\hline & $\begin{array}{l}\text { hours } \\
10 \\
22\end{array}$ & $\begin{array}{c}m U / 100 m l \\
4.47(2.92-6.83) \\
2.47(1.33-4.62)\end{array}$ & $\begin{array}{c}\mu g / 100 m l \\
39 \\
31\end{array}$ & $\begin{array}{c}m g / 2+\text { hours } \\
80\end{array}$ \\
\hline & $\begin{array}{l}10 \\
22\end{array}$ & $\begin{array}{c}15.50(10.40-23.00) \\
\quad 6.50(4.20-9.92)\end{array}$ & $\begin{array}{l}42 \\
49\end{array}$ & 64 \\
\hline \multirow[t]{3}{*}{ T.F. } & $\begin{array}{l}10 \\
22\end{array}$ & $\begin{array}{l}0.14(0.05-0.39) \dagger \\
0.14(0.05-0.40) \dagger\end{array}$ & $\begin{array}{l}29 \\
28\end{array}$ & 11 \\
\hline & $\begin{array}{l}10 \\
22\end{array}$ & $\begin{array}{l}0.48(0.22-1.03) \\
0.77(0.41-1.46)\end{array}$ & $\begin{array}{l}23 \\
26\end{array}$ & 23 \\
\hline & $\begin{array}{l}10 \\
22\end{array}$ & $\begin{array}{l}3.73(2.08-6.70) \\
3.43(1.40-8.39) \dagger\end{array}$ & $\begin{array}{l}57 \\
72\end{array}$ & 62 \\
\hline \multirow[t]{3}{*}{ S.M. } & $\begin{array}{l}10 \\
22\end{array}$ & $\begin{array}{l}0.20(0.08-0.51) \dagger \\
0.34(0.17-0.70) \dagger\end{array}$ & $\begin{array}{l}21 \\
25\end{array}$ & 15 \\
\hline & $\begin{array}{l}10 \\
22\end{array}$ & $\begin{array}{l}0.29(0.12-0.74) \dagger \\
0.30(0.14-0.72) \dagger\end{array}$ & $\begin{array}{l}22 \\
30\end{array}$ & 18 \\
\hline & $\begin{array}{l}10 \\
22\end{array}$ & $\begin{array}{l}2.77(1.46-5.25) \\
1.21(0.45-3.30) \dagger\end{array}$ & $\begin{array}{l}49 \\
54\end{array}$ & 55 \\
\hline
\end{tabular}

+0.82 , a highly significant value $(\mathrm{p}<0.001)$. Above $3 \mathrm{ml}$ per $100 \mathrm{ml}$, additional increments in plasma ACTH failed to bring about further increases in plasma 17-OHCS.

Urinary 17-OHCS were correlated with plasma ACTH concentrations in much the same way (Table II and Figure 4). There appeared to be a rectilinear relationship between urinary 17OHCS and the logarithm of plasma ACTH when ACTH levels were less than $3 \mathrm{ml}$ per $100 \mathrm{ml}$.

TABLE III

Plasma ACTH and 17-OHCS concentrations in 11 patients undergoing major surgery*

\begin{tabular}{|c|c|c|c|}
\hline Patient & Operation & Plasma ACTH & $\begin{array}{l}\text { Plasma } \\
\text { 17-OHCS }\end{array}$ \\
\hline $\mathrm{Bu}$ & Hysterectomy & $\begin{array}{c}m U / 100 m l \\
1.10(0.53-2.24) \dagger\end{array}$ & $\begin{array}{c}\mu g / 100 m l \\
27\end{array}$ \\
\hline My & Hysterectomy & $0.65(0.33-1.28) \dagger$ & 33 \\
\hline Wi & Hysterectomy & $0.61(0.30-1.20) \dagger$ & 23 \\
\hline Wo & Hysterectomy & $0.58(0.20-1.66)$ & 33 \\
\hline Ask & Thyroidectomy & $1.16(0.79-1.72)$ & 32 \\
\hline Har & Cholecystectomy & $0.50(0.24-1.05) \dagger$ & 31 \\
\hline Jo & Hysterectomy & $0.90(0.67-1.48)$ & 36 \\
\hline Dav & Hysterectomy & $0.42(0.13-1.35)$ & 48 \\
\hline $\mathrm{Ca}$ & Hysterectomy & $0.70(0.31-1.58)$ & 41 \\
\hline Bo & Hysterectomy & $0.43(0.15-1.22) \dagger$ & 34 \\
\hline Co & Hysterectomy & $1.11(0.38-3.20) \dagger$ & 37 \\
\hline
\end{tabular}

* The mean estimate of potency is shown for each ACTH determin ation, and $95 \%$ confidence limits are indicated in parentheses.

$\uparrow$ Assays in which responses elicited by the high dose of the unknown were not significantly different from saline controls when compared by
The $r$ for this portion of the curve was +0.82 (significant at $\mathrm{p}<0.001$ ). Above $3 \mathrm{mU}$ per 100 $\mathrm{ml}$, additional increments in plasma ACTH produced no further increase in urinary 17-OHCS. These results suggest that plasma levels of approximately $3 \mathrm{mU}$ of ACTH per $100 \mathrm{ml}$ are sufficient to stimulate maximal adrenocortical activity.

Significant elevations in 17-OHCS could be brought about by increments in plasma ACTH that would have been too small to detect satisfactorily in crude plasma. Only after the extraction procedure could ACTH in concentrations of between 0.5 and $1.0 \mathrm{mU}$ per $100 \mathrm{ml}$ be measured satisfactorily. Even so, such concentrations of ACTH were obviously supraphysiologic, since they induced distinct increases in plasma and urinary 17-OHCS in the normal subjects.

Patients undergoing surgery (Table III). In patients undergoing major surgery, plasma 17 OHCS were elevated, ranging from 23 to $48 \mu \mathrm{g}$ per $100 \mathrm{ml}$, and plasma ACTH concentrations were also elevated to the range of 0.42 to 1.16 $\mathrm{mU}$ per $100 \mathrm{ml}$, with a mean of $0.74 \mathrm{mU}$ per $100 \mathrm{ml}$. These values represent a significant increase when compared with the 6 a.m. values of the group of normal subjects $(p<0.001)$. With one exception, the coordinate values relating 
ACTH to plasma 17-OHCS in the surgical patients fell within the range previously defined for normal subjects receiving ACTH infusions (Figure 3 ); this evidence suggests that the increase in plasma ACTH was in itself a sufficient explanation for the observed increases in 17-OHCS.

Once again, the utility of the extraction procedure for plasma ACTH became apparent, since a large number of the specimens contained less than $1 \mathrm{mU}$ per $100 \mathrm{ml}$ and a satisfactory assay could not have been performed with crude plasma alone.

Patients with Cushing's disease. The correlation between 6 a.m. plasma ACTH concentration and plasma 17-OHCS in 9 patients with untreated Cushing's disease is shown in Table IV. Plasma ACTH ranged from 0.14 to $1.81 \mathrm{mU}$ per $100 \mathrm{ml}$, with a mean of $0.62 \mathrm{mU}$ per $100 \mathrm{ml}$. With two exceptions, the coordinate values for simultaneous plasma ACTH and 17-OHCS concentrations fell within the range observed in normal subjects during continuous infusions of ACTH (Figure 3). While some of the patients with Cushing's disease had plasma ACTH levels comparable to the 6 a.m. levels of normal subjects, others had distinctly elevated plasma ACTH. Taken as a group, the plasma ACTH concentrations of patients with Cushing's disease were significantly higher than the 6 a.m. levels of normal subjects $(\mathrm{p}<0.05)$.

TABLE IV

Plasma ACTH concentrations and plasma and urinary 17-OHCS in 9 patients with Cushing's disease*

\begin{tabular}{|c|c|c|c|c|}
\hline \multicolumn{2}{|c|}{ Patient } & \multirow{2}{*}{$\frac{\text { Plasma ACTH }}{m U / 100 m l}$} & \multicolumn{2}{|c|}{$\begin{array}{c}\text { Plasma Urinary } \\
\text { 17-OHCS } 17-\mathrm{OHCS}\end{array}$} \\
\hline & & & \multicolumn{2}{|c|}{$\mu \mathrm{g} / 100 \mathrm{ml} \mathrm{mg} / 24 \mathrm{hrs}$} \\
\hline Gil & 6 a.m. & $0.66(0.26-1.70)$ & 25 & 25 \\
\hline Par & 6 a.m. & $034 .(0.17-0.70)$ & 16 & 18 \\
\hline $\mathrm{Ki}$ & 6 a.m. & $1.81(1.24-2.65)$ & 34 & 27 \\
\hline Mo & 6 a.m. & $1.20(0.63-2.26)$ & 23 & 35 \\
\hline Bo & 6 a.m. & $0.45(0.14-1.44) \dagger$ & 30 & 20 \\
\hline Lo & $\begin{array}{l}6 \text { a.m. } \\
6 \text { p.m. }\end{array}$ & $\begin{array}{l}0.48(0.24-0.97) \\
0.20(0.06-0.70)\end{array}$ & $\begin{array}{l}31 \\
37\end{array}$ & 41 \\
\hline $\mathrm{Lu}$ & $\begin{array}{l}6 \text { a.m. } \\
6 \text { p.m. }\end{array}$ & $\begin{array}{l}0.14(0.07-0.28) \dagger \\
0.47(0.19-1.20)\end{array}$ & $\begin{array}{l}20 \\
20\end{array}$ & 16 \\
\hline Gal & 6 a.m. & $0.15(0.06-0.36) \dagger$ & 19 & 16.4 \\
\hline $\mathrm{Hu}$ & 6 a.m. & $0.36(0.19-0.68)$ & 53 & 38 \\
\hline
\end{tabular}

* The mean estimate of potency is indicated for each ACTH determination, and $95 \%$ confidence limits are indicated in parentheses.

+ Assays in which responses elicited by the high dose of the unknown were not significantly different from saline controls when compared by $t$ test (one-tailed, p > 0.05).
DISCUSSION

Our experience agrees with that of several others (1-4) in indicating that the concentration of ACTH in the plasma of normal subjects is too low to be measured satisfactorily by direct assay of the unextracted plasma. With preliminary extraction of the hormone from the plasma, however, it is possible to administer assay doses eliciting responses large enough to permit the construction of dose-response curves and the calculation of potencies and confidence limits by standard statistical procedures. Even then, when only 3 assay animals are used at each dose level, some specimens do not elicit responses significantly different from saline controls. By combining data from assaying several like specimens, however, it is often possible to derive statistically significant results. Apparently, such methods must be employed if attempts to discriminate normal from moderately elevated ACTH levels are to have any meaning. Because of methodological difficulties, differences that are of great physiological significance have often been difficult to demonstrate as statistically significant.

The present study indicates that the normal human adrenal cortex is remarkably sensitive to small quantities of ACTH. The diurnal increase in cortisol secretion occurring during the early morning hours is attributable to ACTH concentrations of the order of $0.25 \mathrm{mU}$ per 100 $\mathrm{ml}$. Later in the day, cortisol secretion diminishes greatly, as plasma ACTH concentrations fall to levels of the order of $0.11 \mathrm{mU}$ per $100 \mathrm{ml}$.

The rise in plasma ACTH observed in surgical patients was similar to that recently reported by Cooper and Nelson (6). Presumably, the rise in plasma $17-\mathrm{OHCS}$ occurring during surgery is attributable to this increase in plasma ACTH. The adrenal gland only rarely exhibits a maximal secretory response to surgery. This is consistent with our observation that, in the surgical patients, plasma ACTH did not attain concentrations in excess of the $3 \mathrm{mU}$ per $100 \mathrm{ml}$ that would evoke maximal adrenocortical activity.

Our work indicates that the 6 a.m. plasma ACTH levels of some patients with untreated Cushing's disease are normal, whereas those of others are distinctly elevated. Yet when these assays are taken as a group, the mean value $(0.62$ 
$\mathrm{mU}$ per $100 \mathrm{ml}$ ) is significantly greater than the mean value $(0.25 \mathrm{mU}$ per $100 \mathrm{ml})$ of a group of normal subjects at 6 a.m. Patients with Cushing's disease lack diurnal variation in plasma 17-OHCS (21). Since 17-OHCS secretion is apparently a function of ACTH in these patients, probably they also lack normal diurnal variation in ACTH secretion. Even though their plasmaACTH levels might be normal at 6 a.m., their total daily production of ACTH (and 17-OHCS) might well be excessive.

The findings of this study confirm and extend those of Davies (22) indicating that ACTH is elevated in patients with untreated Cushing's disease. These observations are also consistent with those of Jailer, Longson, and Christy (23), who, using adrenal weight maintenance as the index of biological activity, found increased concentrations of a corticotrophic agent in the plasma of patients with Cushing's disease.

\section{SUM MARY}

Through the use of a method for extracting ACTH from plasma in preparation for biological assay, it has been possible to obtain statistically meaningful information concerning the concentrations of ACTH in the plasma of normal subjects, patients with Cushing's disease, and patients undergoing major surgery. Plasma ACTH concentrations have been correlated with adrenocortical activity, as reflected in plasma and urinary 17-hydroxycorticosteroids (17-OHCS).

In normal subjects, the diurnal rise in plasma 17-OHCS was associated with a mean plasma ACTH concentration of $0.25 \mathrm{mU}$ per $100 \mathrm{ml}$ at 6 a.m. The diurnal decline in plasma 17-OHCS was accompanied by a fall in ACTH concentrations to a mean value of $0.11 \mathrm{mU}$ per $100 \mathrm{ml}$ at 6 p.m. To extend the range of observations correlating adrenocortical activity with plasma ACTH concentrations, we infused $\mathrm{ACTH}$ at constant rates for 24-hour periods in normal subjects. Plasma and urinary 17-OHCS appeared to be rectilinear functions of the logarithm of plasma $\mathrm{ACTH}$ concentrations, as long as the latter did not exceed $3 \mathrm{mU}$ per $100 \mathrm{ml}$. At or above this concentration of plasma ACTH, maximal adrenocortical activity was observed.

In 11 endocrinologically normal patients under- going major surgery, the usual increases in plasma 17-OHCS were associated with significant increases in plasma ACTH concentrations, with a mean value of $0.74 \mathrm{mU}$ per $100 \mathrm{ml}$.

In patients with untreated Cushing's disease, elevated plasma and urinary 17-OHCS were associated with, and were presumably a result of, elevated plasma ACTH concentrations. The mean value of $0.62 \mathrm{mU}$ per $100 \mathrm{ml}$ for a series of 9 patients with Cushing's disease was significantly greater than that of a group of normal subjects $(p<0.05)$.

\section{ACKNOWLEDGMENT}

Dr. Charles F. Federspiel of the Department of Preventive Medicine, Vanderbilt University School of Medicine, generously provided assistance in the statistical analysis of the data presented in this paper.

\section{REFERENCES}

1. Sydnor, K. L., G. Sayers, H. Brown, and F. H. Tyler. Preliminary studies on blood ACTH in man. J. clin. Endocr. 1953, 13, 891.

2. Taylor, A. B., A. Albert, and R. G. Sprague. Adrenotrophic activity of human blood. Endocrinology 1949, 45, 335.

3. Fujita, T. Determination of corticotropin (ACTH) in human blood and urine by a modified oxycellulose method. J. clin. Endocr. 1957, 17, 512.

4. Nelson, D. H. Disorders of ACTH secretion in man. Metabolism 1961, 10, 894.

5. Lipscomb, H. S., and D. H. Nelson. A sensitive biologic assay for ACTH. Endocrinology 1962, 71, 13.

6. Cooper, C. E., and D. H. Nelson. ACTH levels in plasma in preoperative and surgically stressed patients. J. clin. Invest. 1962, 41, 1599.

7. Vance, V. K., W. J. Reddy, D. H. Nelson, and G. W. Thorn. Adrenocorticotropic hormone in human plasma. J. clin. Invest. 1962, 41, 20.

8. Bliss, C. I. The Statistics of Bioassay. New York, Academic Press, 1952, pp. 483-487.

9. Paris, J., M. Upson, Jr., R. G. Sprague, R. M. Salassa, and A. Albert. Corticotropic activity of human blood. J. clin. Endocr. 1954, 14, 597.

10. Sayers, G. Blood ACTH. J. clin. Endocr. 1955, 15, 754.

11. Munson, P. L. Adrenocorticotropic hormone in Hormones in Human Plasma, H. N. Antoniades, Ed. Boston, Little, Brown, 1960, p. 149.

12. Williams, W. C., Jr., D. Island, R. A. A. Oldfield, Jr., and G. W. Liddle. Blood corticotropin (ACTH) levels in Cushing's disease. J. clin. Endocr. 1961, 21, 426.

13. Liddle, G. W., D. Island, and C. K. Meador. Normal and abnormal regulation of corticotropin se- 
cretion in man. Recent Progr. Hormone Res. 1962, 18, 125.

14. Liddle, G. W. Tests of pituitary-adrenal suppressibility in the diagnosis of Cushing's syndrome. J. clin. Endocr. 1960, 20, 1539.

15. Liddle, G. W., H. L. Estep, J. W. Kendall, Jr., W. C. Williams, Jr., and A. W. Townes. Clinical application of a new test of pituitary reserve. J. clin. Endocr. 1959, 19, 875.

16. Peterson, R. E., A Karrer, and L. S. Guerra. Evaluation of Silber-Porter procedure for determination of plasma hydrocortisone. Analyt. Chem. 1957, 29, 144.

17. Liddle, G. W., J. E. Richard, and R. E. Peterson. An improved method for assaying the steroidogenic potency of ACTH. Endocrinology 1955, 57, 594.

18. Munson, P. L., and W. Toepel. Detection of minute amounts of adrenocorticotropic hormone by the effect on adrenal venous ascorbic acid. Endocrinology 1958, 63, 785.
19. Silber, R. H., R. D. Busch, and R. Oslapas. Practical procedure for estimation of corticosterone or hydrocortisone. Clin. Chem. 1958, 4, 278.

20. Sayers, M. A., G. Sayers, and L. A. Woodbury. The assay of adrenocorticotrophic hormone by the adrenal ascorbic acid-depletion method. Endocrinology 1948, 42, 379.

21. Ekman, H., B. Håkansson, J. D. McCarthy, J. Lehmann, and B. Sjögren. Plasma 17-hydroxycorticosteroids in Cushing's syndrome. J. clin. Endocr. 1961, 21, 684.

22. Davies, B. M. A. Blood corticotrophin in Cushing's syndrome in The Human Adrenal Cortex, A. R. Currie, T. Symington, and J. K. Grant, Eds. London, E. and S. Livingstone, 1962, p. 468.

23. Jailer, J. W., D. Longson, and N. P. Christy. Studies in Cushing's syndrome. II. Adrenal weight-maintaining activity in the plasma of patients with Cushing's syndrome. J. clin. Invest. 1957, 36, 1608. 